\title{
The Poumai Naga Agricultural Festivals and Rituals vis-a-vis Folklores: Covid-19 Pandemic Application
}

Paul Punii is a research scholar from Assam Don Bosco University

Dominic Meyieho is an Assistant Professor at Assam Don Bosco University

\section{Abstract}

The traditional Poumai Naga People are basically agrarian and their lives revolve around it. Poumais are distributed into Paomata, Chilivai, Lepaona, and Razeba. As agrarian people they sow paddy; Daonü, Tainü, Marunü, Louka are festivals to usher the sowing of paddy. Duh is the ritual celebration for good seed. Paoki is the feast of plantation. Laonü is the post plantation festival. Nge is ritual celebration asking God to preserve the paddy from the attack of pestilence. Baoloutouyu is the prayer for abundance and eating of the first fruits. Thounü is the New Year thanksgiving celebration with abundance of food and wine. The festivals and rituals that preserve a community act as a deterrent to exceptional events like the Pandemic in the community history is a subterranean argument in the paper.

Keywords: Festivity, folklores, pandemic, Poumai rituals, agrarian practices.

\section{Introduction}

All over the world, the year 2020 has been badly affected by the Covid-19 pandemic. The paper will examine the 'Poumai Naga' Agricultural festivals and rituals in the light of the Covid-19 pandemic. The Poumai is a major Naga tribe with a population of 1,79,189 as per 2011 census. ${ }^{1}$ The Poumai Nagas are basically an

${ }^{1}$ The total area of the Poumai land covers $1,200 \mathrm{sq} . \mathrm{km}$. There are 81 Poumai inhabited villages of which 68 are revenue recognized villages and 13 are unrecognized. The Poumai villages basically fall under three Sub-Divisions namely, Paomata SDO/ $\mathrm{BDO}$, Purul SDO/BDO, Phaibung SDO/BDO, some of the villages are under Kangpokpi Sub-Division and some in Phek District of Nagaland under Razeba circle. The Poumai Nagas are situated in the north district of Manipur and south of 


\section{8 / Paul Punii \& Dominic Meyieho}

Salesian Journal of Humanities and Social Sciences, Vol. XI, No.2 (Dec 2020)

ISSN: 0976-1861 | DOI: 10.51818/SJHSS.11.2020.77-105 | Page: 77-105,

Section: Articles

agrarian society, hence it closely observes the phases of the moon and the seasonal cycles. The rhythm of daily life throughout the year is affected and organised around the agrarian calendar. As a society where farming is hugely important for the subsistence of its members, it has developed a great variety of semi-religious events where prayers and rituals are offered for bountiful harvest, prayers for protection of crops from pestilence and stormy weather. These practices have gradually developed into community celebrations and festivals, and consequently they are the culture of the folks. Alan Dundes would call Folklore as a "mirror of culture," ${ }^{2}$ hence if anyone wants to know the culture of the Poumai Nagas, they will have to study the rituals and festivals which form the soul of Poumai folklore.

\section{Agricultural Rituals and Festivals}

The life of the Poumais basically moves along with the agricultural activities. Their live depends on the agricultural produce. And for good crop they depend on the timely arrival of the monsoon and good weather conditions. The different agricultural festivals celebrated by the Poumai Nagas indicate the ushering of different seasons of the lunar calendar. These festivals are replete with rituals, practices and celebrations. They are significant expressions of a group's tradition, beliefs, values and identity. ${ }^{3}$ Let us make a quick run through into what a ritual and festival are.

\section{Ritual}

Ritual is ordinarily understood as a religious or solemn ceremony involving a series of actions performed according to a prescribed order. Writing on Ritual Roy A. Rappaport, gives three types of meaning to Ritual. First, ritual is understood to be a form or

Nagaland.

2 Simon J. Bronner, The Meaning of Folklore: The Analytical Essays of Alan Dundes (Logan, Utah: Utah State University Press, 2007), 55.

${ }^{3}$ Martha C. Sims and Martine Stephens, Living Folklore: An Introduction to the Study of People and Their Traditions (Logan, Utah: Utah State University Press, 2005), 95. 
The Poumai Naga Agricultural Festivals and Rituals vis-a-vis Folklores... / 79

Salesian Journal of Humanities and Social Sciences, Vol. XI, No.2 (Dec 2020)

ISSN: 0976-1861 | DOI: 10.51818/SJHSS.11.2020.77-105 | Page: 77-105,

Section: Articles

structure, that is, a number of features or characteristics in a more or less fixed relationship to one another.

A second feature noted in the definition is performance. If there is no performance, there is no ritual; performance itself is an aspect of that which is performed. The medium is part of the message; more precisely, it is a metamessage about whatever is encoded in the ritual.

The, third definition stipulates that the sequence of formal acts and utterances constituting ritual are not absolutely invariant but only more or less so. This stipulation not only allows for imperfection in performance but also recognizes that some variation will likely be present within any liturgical order (ritual) no matter how punctilious its performance must be. ${ }^{4}$

\section{Messages Transmitted in Ritual}

Ritualistic actions are performed in the belief that it will produce an effect; hence every action will have a meaning and a purpose. The very existence of variant and invariant aspects of ritual implies that two classes of messages are being transmitted. First, the apparently changeless messages signified by the invariant order of the ritual's canon. These are concerned with the enduring aspects of the social and cosmological order. Second, messages carried by whatever variation the ritual allows or requires.

The relationship of sign to signified in each of these two classes of messages may be different. That which is signified by the invariant canon is not confined to the here and now, may not be material, and, as in the case of transcendent deities, might not even be thought to exist in the space-time continuum. Since these significant are not present in their entirety, their signification requires the use of symbols.

4 Roy A. Rappaport, "Ritual," in Folklore, Cultural Perfomance and Popular Entertainments Richard Bauman(ed.), (New York, Oxford: Oxford University Press, 1992), 249-250. 


\section{0 / Paul Punii \& Dominic Meyieho}

Salesian Journal of Humanities and Social Sciences, Vol. XI, No.2 (Dec 2020)

ISSN: 0976-1861 | DOI: 10.51818/SJHSS.11.2020.77-105 | Page: 77-105,

Section: Articles

In contrast, the state of the performers signalled by variations in performance exists in the here and now. As such, the relationship of the sign to the signified need not be symbolic, but may be indexical. A dark cloud for instance, is an index of rain.

Ritual, in sum, is not simply a collection of messages and metamessages but a complex form of communication in which the two sorts of messages are mutually dependent. ${ }^{5}$

\section{Festival}

The common understanding of a festival is that, it is a day or a period of celebration typically for religious reasons. Festivals occur at calendrically regulated intervals and are public in nature, participatory in ethos, complex in structure and multiple in voice, scene, and purpose. Festivals are collective phenomena and serve purposes rooted in group life. Systems of reciprocity and of shared responsibility ensure the continuity of and participation in the festival through the distribution of prestige and production. Stoeltje would say, "Most festivals provide the opportunity for individual religious devotion or individual performance, and this opportunity is a primary motive for the occasion." Furthermore Stoeltje states there are other unstated but important purposes of festivals, like the expression of group identity through ancestor worship or memorialisation, the performance of highly valued skills and talents, or the articulation of the group's heritage. Sometimes they may not even use the word festival but use a name that is related to the purpose or core symbols of the event. ${ }^{6}$

\section{Ritual and Festival}

From the definition given above we can understand that there is a relationship between ritual and festival. A ritual is often related

\footnotetext{
${ }^{5}$ Rappaport, "Ritual," 251.

6 Beverly J. Stoeltje, "Festival," in Folklore, Cultural Performance and Popular Entertainment, Richard Bauman(ed.), (New York, Oxford: Oxford University Press, 1992), 261.
} 
to religion, though it can stand alone. Similarly, there are religious festivals but festivals need not have any connection to religion as well. However, in the Poumai Naga performance of rituals and celebrations of festivals, they form part of the cultural ethos of the people. The presentation and description of these rituals and festivals will bring forth the Poumai Naga corpus of historicocultural heritage while trying to identify values, retrieve the lost, and create an identity.

The Poumai Nagas in general observe two ritual days and celebrate mostly agricultural festivals:

1. Duh: Ritual observation for good plants

2. Nge: Ritual observation for good weather and protection from pestilence

3. Daonü/Maruni/Tainü/Louka: Seed Sowing Festival

4. Paoki/Apao Soupya: Feast and plantation Ritual

5. Laonü: Post-plantation festival

6. Baolou touyu: Feast of thanksgiving

7. Thounü: Feast of new crops

The Poumais in general observe this rituals and festivals, but not at the same time. Different villages observe and celebrate these festivals at different times, as the villages are spread over several mountain ranges with slight variations of climatic conditions. Besides, the same feast is celebrated with greater or lesser degree of gaiety depending on the village. The village Chief announces the beginning of these celebrations and the people readily participate in it. The festivals continue to be celebrated annually maintaining essentially the same form, while their original meaning has sometimes been forgotten. As Smith would say, "the enduring significance of the festival lies less in its avowed purpose or meaning than in the fact of celebration itself." ${ }^{7}$

\footnotetext{
${ }^{7}$ Robert J. Smith, "Festivals and Celebrations," in Folklore and Folklife, ed. Richard M. Dorson (Chicago and London: The University of Chicago Press, 1982), 160.
} 


\section{2 / Paul Punii \& Dominic Meyieho}

Salesian Journal of Humanities and Social Sciences, Vol. XI, No.2 (Dec 2020)

ISSN: 0976-1861 | DOI: 10.51818/SJHSS.11.2020.77-105 | Page: 77-105,

Section: Articles

The celebration of festivals according to Smith can be considered as "a major class of folklore, one that may include within itself almost all the others as subclasses." 8 The celebration of festivals is preceded by ritualistic prayer and oblations to the deity. Every agricultural festival that is celebrated by the Poumai folks has a corresponding ritual and oblation that precedes the celebration. The festival bring people together to a common platform for singing and dancing, eating and drinking, recalling of momentous historical events, and narrating folktales etc. It is on these festivals that the inhabitants of the region wear their traditional costumes and keep up their culture.

Thus, looking at the various activities of the festivals we concur with Smith who says that, "the prime function of the festival is to provide occasion and form for positive group interaction, which is a necessary condition for the continued existence of the group." ${ }^{\prime 9}$ These events in the life of the people are fostered from generation to generation and they have become a folk-culture and folklore. We shall now present the various agricultural festivals and rituals. It may however be noted that due to the outbreak of COVID-19, there was no public gathering and celebration of any sort, though families had their celebrations.

\section{Seed Sowing Festival}

Rice is the staple food of the Poumai people and hence the sowing of paddy is done with great sacredness. The ritual for sowing of paddy seeds is observed with great care and sacredness in all villages but the pomp of the accompanying feast depends on the individual village. The Poumais are distributed into a large mountainous area and hence sowing and plantation of paddy occur at slightly different times.

\footnotetext{
${ }^{8}$ Smith, "Festivals and Celebrations," 168.

${ }^{9}$ Smith, "Festivals and Celebrations," 168.
} 
The Poumai Naga Agricultural Festivals and Rituals vis-a-vis Folklores... / 83

Salesian Journal of Humanities and Social Sciences, Vol. XI, No.2 (Dec 2020)

ISSN: 0976-1861 | DOI: 10.51818/SJHSS.11.2020.77-105 | Page: 77-105,

Section: Articles

\section{Daonü/Seed Sowing}

Daonü is celebrated among Proumai villages (Phaibung subdivision) like Kodom, Lakhamai, Sirong and Shimai. The ritual begins on the $17^{\text {th }}$ day of the lunar calendar of Roupa (March). This is the first day on which animals are killed in preparation for the celebration. On this day daughters who are married to men from other villages and relatives and guests arrive at the village for the celebration. These daughters are invited to all the houses of the uncles. And in the evening lots of meat (souveh) are packed for their journey back to their homes. On return they share this meat with all their in-laws, and also give a feast to the children. ${ }^{10}$

On the second day, Chidzü (dedication of prayer to the home deity) ritual prayer and offering libation to the house deity is performed. It is a day of genna (day of ritual observation and refrain from work). The father of the family performs this ritual near the rüph - the central pillar, which is also the altar of the house, fasts till noon. Two receptacles like cups are folded from a single plantain leaf, making sure that the two cups are taken from either side of the leaf - right side for grandpa and left side for grandma. Wine is poured into the plantain cup and offered to deity grandma Tro and grandpa Hralu, saying "Ra paipaoh, nehai zaoprai vei sohlou-o. Come and be served your cup of wine grandma Tro and grandpa Hralu." The rest of the plantain leave is left covering the cups. ${ }^{11}$

In the evening when the household is about to sleep, the mother finally offers food to grandma Tro and grandpa Hralu. The ritual is termed as Hrailu thro thro. Two leaves are torn from a single plantain leaf to serve as plate for grandma Tro and grandpa Hralu. A little bit of meat is placed in the plantain leaf, and ginger is pinched and placed in the plate and offered to the house deities grandma Tro and grandpa Hralu saying, "Pai Tro eh Paoh Hralu, nehai tou eh zao vei

${ }^{10}$ Kuchaoru K. Jenny, "Daonii Festival in Zhamai, Lakhamai," interview by Paul Punii, 0ctober 16, 2016.

${ }^{11}$ Loura Haba, “Laonii Festival in Zhaimai Village," interview by Paul Punii, July 15, 2016. 


\section{4 / Paul Punii \& Dominic Meyieho}

Salesian Journal of Humanities and Social Sciences, Vol. XI, No.2 (Dec 2020)

ISSN: 0976-1861 | DOI: 10.51818/SJHSS.11.2020.77-105 | Page: 77-105,

Section: Articles

tou-sou lou-o. Grandma Tro and Grandpa Hralu, come and partake this food and wine to your heart's content. Protect us from all evil." The mother distributes the ginger or meat saying $1,2,3,4,5,6,8$, 9, 10, (avoiding 7 in between). Grandma's plate 20, grandpa's plate 30, don't know, you divide among yourselves (tshü tsha lou ho, nai mai lya pi phya tou lou -o). Number 7 (seven) is believed to be a perfect number and hence the fear of unequal distribution makes the people to leave out the number seven. Then she keeps the plate at the rüphi, corner of the house and goes away. The ritual ends with this offering and appeasing of the house deity.

In the afternoon of this day young men gather to wrestle and prove their strength and masculinity. Men even from neighbouring villages come to compete in the wrestling. The third day is called Shepao where all guests and relatives were given a send-off with packs of food for their journey.

The fourth day is called Nü ra nai another day of observation of the feast. The village chief or the priest would get a blameless cock, split it from the mouth down to sight the omen. If lots of blood oozes from the chicken the monsoon is believed to be good and on time, if not there would be drought. Another omen or belief concerning the feast of Daonü is shower during this feast. Rain during this festival is a good omen for favourable monsoon and vice-versa. ${ }^{12}$

The priest or chief of the village who officiates the ritual collects two shoots of Mousü (rhus glabra plant) and a handful of Laipa (flower plant) and places them together in the field. The Mousü and Laipa are symbolically chosen for the abundant yield of their seeds. The village chief would then pray thus, "O God, may our rice grow like that of the seeds of Mousü and Laipa and may it yield a good harvest" (Oh Ramai, e-rimai thou panou, moushi, eh laipapah kanou mache lou-o, eh panou cha veilou-o). After the performance of this ritual, the people may start to plant various crops and sow paddy. ${ }^{13}$

${ }^{12}$ Jenny, “Daonii Festival in Zhamai, Lakhamai," 0ctober 16, 2016.

${ }^{13}$ David Ng. Sha, "The Poumai Naga Traditiona Rites and Rituals," in Poumai 
The Poumai Naga Agricultural Festivals and Rituals vis-a-vis Folklores... / 85

Salesian Journal of Humanities and Social Sciences, Vol. XI, No.2 (Dec 2020)

ISSN: 0976-1861 | DOI: 10.51818/SJHSS.11.2020.77-105 | Page: 77-105,

Section: Articles

\section{Marunï/ Seed sowing}

Marunü is observed by three Ngari villages. They occupy the northeastern part of Poumai villages. This is the first day of the feast and they prepare for the feast by hunting and killing of animals on the $12^{\text {th }}$ Roupa (March) of the Lunar calendar. The daughters married to men in other villages and guests arrive at the village on this day.

On the second day the ritual of Chidzü (prayer to the deity of the house) is performed. It is a day of genna where people refrain from work. The daughters are invited to the parent's house and are fed with good food and drinks. However the sisters do not sleep in

their parent's house but at the house of their brothers or relatives, to show that they do not belong to the house any longer. In the evening young men compete in the wrestling as part of the festival.

On the third day Shepao, the daughters and relatives are given a send-off with food and meat packed for the journey and the relatives.

On the fourth day Nü ra nai the priest (or village chief in some cases) would pick a blameless cock, split it from the mouth down to see the omen. Then the blood is smeared with the paddy seed for the sowing, to signify life and fertility. The following day all the people go to sow paddy seeds in their own plots. ${ }^{14}$

\section{Tainii/Seed sowing}

In Lepaona area (Purul sub-division) the sowing of seeds is called Taimou thouyu. The sowing of seeds begin during the last part of the month of Süpa (February) and early part of Roupa (March). On the appointed day, the village chief goes to the field and offers ginger and libation to the deity, and sows the seeds. Then he comes home Thounii Celebration: Our Culture is our Identity, Paul Punii(ed.), (Senapati: Poumai Naga Union, 2016), January 4-6, 32-35.

${ }^{14}$ Jenny, "Daonii Festival in Zhamai, Lakhamai," 0ctober 16, 2016. 


\section{6 / Paul Punii \& Dominic Meyieho}

Salesian Journal of Humanities and Social Sciences, Vol. XI, No.2 (Dec 2020)

ISSN: 0976-1861 | DOI: 10.51818/SJHSS.11.2020.77-105 | Page: 77-105,

Section: Articles

and fasts and keeps the day sacred. The general public goes to sow seeds the following day. ${ }^{15}$

\section{Pya manai/ Louka/Seed sowing genna}

In Paomata area under Paomata sub-division there are two times when the seeds are sown; one for millet and the other for paddy. One day is set aside for observation of the ritual. It is a genna day. The people in the village are to abstain from work and activities such as; making baskets, weaving, and journey. They are not to hunt for bee hives, wasps and hornet combs. Even the married couples are to abstain from all conjugal signs of affection and relationships on those days of the ritual observation. The people have simple vegetarian meal with sesame seeds. The following day seeds can be

sown. Millet is sown during the latter part of Thounü khou (January). The time is termed as pya rai first sowing. ${ }^{16}$

There is a feast to celebrate the beginning of the sowing of paddy seeds called Louka. On the first day after the new moon the young men of the village go to catch the bird sei, (thrush) catching with bare handed according to khels (clans). Once the bird is caught, they impale the bird on a long stick and march towards the khel gate and plant the head there as a trophy. In the evening all go home for celebration with best of food and drinks. On the following day, youngsters according to categories take part in wrestling. The strongest and the most skilful winner is honoured and respected in the village. The following day onwards the people can go for sowing paddy. Paddy seeds are sown after the new moon of Roupya (March).

\section{$D u h /$ Ritual for Timely Monsoon}

The National lockdown due to COVID-19 had already been imposed long way by the time the ritual of Duh was to be observed.

${ }^{15}$ Souphio Samuel, "Taimou Thouyu," interviewed by Paul Punii, October 16, 2016.

${ }^{16}$ Punii Michael, "Laonii Festival of the Poumai Nagas," interview by Paul Punii, July 13, 2016. 
By this time the people were well aware that COVID-19, was a pandemic and people certainly were informed to seriously observe this genna day, to pray to god and to be freed from the attack of droughts, pandemic, and for favourable weather and monsoon. It was believed that the sincere and sacred observation of these days will ward off all droughts, epidemics.

It used to be an oft-repeated reminder by the elders to warn the youngsters not to violate the sanctity of the ritual days of Duh and Nge. The elders would reprimand the undisciplined people saying, Taomai, nahmai, Duh eh Nge zhai sou-o. Rahri, rahtah, vei lou dzii matsi lai-Grandchildren and Children, do not defy the ritual days of Duh and Nge. Else you will be punished when the epidemic or pandemic comes. ${ }^{17}$

This ritual is observed to invoke god's blessing for timely and sufficient rain water for the success of paddy seed transplantation. The people would worship the sky and the earth for a favourable time for transplantation of paddy seeds. It is two days observation of the ritual without work at the beginning of May before the plantation begins. The ritual Chidzü and Hrailu thro thro - prayers, food and libation to the home deity are offered.

The previous night water is fetched from the ritual pond for the next day's ritual. In the morning yeast is powdered and put in the gourd and poured into the two cups made from plantain leaf. Mixture from the gourd is poured into the plantain cup and offered to deity grandma Tro and grandpa Hrailu, saying "come and be served your cup of wine grandma Tro and grandpa Hralu" (Pai tro eh pao Hrailu, nehai prai vei solou-o). The rest of the plantain leave is left covering the cups.

In the evening when all activity of the day is over the mother prepares two plantain leaves like plate and places few pieces of uncooked rice and pieces of ginger into the plates of the deities

17 Hriinii T. Henry, “On Epidemic and Pandemic," interview by Paul Punii, October, 30, 2020. 


\section{8 / Paul Punii \& Dominic Meyieho}

Salesian Journal of Humanities and Social Sciences, Vol. XI, No.2 (Dec 2020)

ISSN: 0976-1861 | DOI: 10.51818/SJHSS.11.2020.77-105 | Page: 77-105,

Section: Articles

grandma tro and grandpa hralu. When food is distributed the mother counts till 10 taking care to avoid the number 7. "You may share and divide equally yourself." (li, hai, sü, dai, ngao, zi, cha, ke, kiru. Pai zha make, pou zha shirou, madeimo bu-a, nehai lya phiphya lou.) Then the family goes to rest. ${ }^{18}$

These two days are days of religious observance. It is a genna to go to the field. The people in the village are to abstain from games, work and activities such as; making baskets, weaving, and journey. Even the married couples are to abstain from all conjugal signs of affection and relationships. The faithful observance of these days is believed to appease God and give sufficient rain for the transplantation. ${ }^{19}$

\section{Paddy Plantation/ Thao Shodi}

The plantation of paddy is another great event in the life of the Poumai people. The beginning of the paddy plantation is done with religious sacredness. The Leopaona area (Purul Sub-division) calls it Paoki while the other Poumai areas content with the ritual of Apao soupya - cutting of meat for offering to the deity and family consumption.

\section{Paoki/ Paddy plantation season}

Paoki means paddy plantation season. It is a celebration to usher in plantation of paddy - rice that is eaten throughout the year. Paoki is celebrated with great pomp and enjoyment in Leopaona area particularly in Purul by both the rich and poor people alike. In this feast good wine is prepared and lots of meat and fish too. At this time the daughters who are married off to other villages and family guests and friends from other villages are also invited. All those who arrive for this feast are accorded great hospitality.

Paoki is celebrated for three days, ranai, thaopai, lu shoyu theithe. On ranai animals like dogs, pigs, cows and buffaloes and chickens

${ }^{18}$ Michael, "Laonii Festival of the Poumai Nagas," July 13, 2016.

${ }^{19}$ Michael, "Laonii Festival of the Poumai Nagas," July 13, 2016. 
The Poumai Naga Agricultural Festivals and Rituals vis-a-vis Folklores... / 89

Salesian Journal of Humanities and Social Sciences, Vol. XI, No.2 (Dec 2020)

ISSN: 0976-1861 | DOI: 10.51818/SJHSS.11.2020.77-105 | Page: 77-105,

Section: Articles

are killed for celebration. The following day called Thaopaiyu the paddy seedlings are plucked and gathered. On this day the relatives and friends and guests arrive at the village. In the evening there is wrestling competition among the village youth and against young men from other villages. Once wrestling is over, in the evening the young boys and girls gather for singing competition. It is a time when young boys and girls come to know their special qualities and court each other. ${ }^{20}$

Early the next day at dawn the mother first goes to the field and offers small meat pieces in the corner of the field, pinches ginger and throws into the field and also offers libation to the deity (tips a little wine in the field) saying the following prayers:

Deiro thou paou, ngaopathou lelou tesou, aliro khai poteivei lurouthou shothou khaitiyu taimohihai khao raohou aliro tekhai raroshi peima vedaimore donou... ${ }^{21}$ (Let the earth bring forth abundantly... and let the paddy that has been planted for this year, be not destroyed by animals or birds, and let it not be destroyed by wind and storm).

\section{Apao Soupya/Meat for the plantation season}

In Paomata, Razeba and Chilivai areas (north and north-east Poumai) there is the cutting of animals on the first day. Early the next morning the mother first goes to the field, tears pieces of meat, ginger and keeps in the corner of the field and also offers libation to the deity (tips a little wine in the field) saying the prayers:

- Pa teithi avei zou pa sho dao lou-a (Let the seedlings be planted on a good day)

- Pa teithrai teirü ashi sou mashi mo-a (Let it not be spoiled by the wind and rain)

- Pa mara mari panou trou dei sou-ah (Let it not be hit by hailstones)

- Pa beidu, trodu-a (Let it have big stalks, heavy with grains)

${ }^{20}$ Heshoru Dio, Paih-Pao Maivei Zhaidou (Purul Atongba: Heshoru Dio, 2009), 19.

${ }^{21}$ Dio, Paih-Pao Maivei Zhaidou, 19. 


\section{0 / Paul Punii \& Dominic Meyieho}

Salesian Journal of Humanities and Social Sciences, Vol. XI, No.2 (Dec 2020)

ISSN: 0976-1861 | DOI: 10.51818/SJHSS.11.2020.77-105 | Page: 77-105,

Section: Articles

- Pa ratsi thou avei matsi lou-o. (Be blessed with abundant fruits).

- Pa chavei sou-ah pa vah lou-o (Give us a bountiful harvest). ${ }^{22}$

\section{Laoniu/ Post-Plantation Festival}

Laonü is a post-plantation festival of the Poumai Nagas. The people celebrated the feast in a very sober manner due to COVID-19, without much fanfare and gathering. This festival is celebrated in the month of Lao (July) after all the people in the village have completed paddy transplantation. All farmers are supposed to complete paddy transplantation before the festival. If paddy transplantation could not be completed in any part of the field, it is left fallow for that year. In cases of the late arrival of the monsoon, the month is extended as Lao hai (July II). In this case the month of Lai (August) is omitted to proceed with Nge (September) ${ }^{23}$ The Poumai villages celebrate Laonü at different times depending on the climatic condition, and completion of paddy transplantation.

The Laonü festival is celebrated for five days. The Laonü festival incorporates many other important motifs of celebrations like ritual for house warming, prayer and performing of the ritual for good crop, ceremony of the purification for male children, offering prayers and food to the house deity, social festival (Morung fest), wrestling, prayer for protection etc. Each of these motifs is celebrated on different days of the Laonü festival. The motifs will be explained on the different days.

\section{Paonü chüche/ Gathering Firewood}

This is the first day of the festival. There are two motifs celebrated on this day. Firstly this is the beginning day of the feast. Early in the morning boys in the morung perform the Mou kho di (praying for abundance and good fruit) ceremony. The prayer should be pronounced only in the morning when all the members are ready.

\footnotetext{
${ }^{22}$ Michael, "Laonii Festival of the Poumai Nagas," July 13, 2016.

23 Saloni Pao, "The Laonii Festival," The Morung Express, July 15, 2007.
} 
The Poumai Naga Agricultural Festivals and Rituals vis-a-vis Folklores... / 91

Salesian Journal of Humanities and Social Sciences, Vol. XI, No.2 (Dec 2020)

ISSN: 0976-1861 | DOI: 10.51818/SJHSS.11.2020.77-105 | Page: 77-105,

Section: Articles

The host of the morung begins the ceremony crying aloud:

Elder: Painao dzüthou dei kou de she (The egg / seed of the deity Painao has been given)

Boys: tre, tre, tre, tre (makes the sound tre)

Elder: Oh, tshi ludu, lu ludu, tsa-mou che-a, pei pai-a laide she

(Oh, through south and $L u$ road, they are coming laden with fruits, and hairs falling due to heavy burden).

Boys: tre, tre, tre, tre (makes the sound tre)

Elder: Oh, Chea ludu, Ri ludu, tsa-mou che-a, pei pai-a laide she

(Oh, through Chea and forest road, they are coming laden with fruits, and hairs falling due to heavy burden).

Boys: tre, tre, tre, tre (makes the sound tre)

Elder: Then he pronounces the final blessing thus,

Tshrai, tshrai pya heu tshrai dei kuo (let it be as tasty as the sharpened spear would bring).

Thrai, thrai pya amou kai kuo (let it be as sour as the amou tchü fruit)

Haihinou vei tsulai dei (we shall begin afresh from here). ${ }^{24}$

The refrain tre, tre, tre, should have a rhythm and it should not be broken till the final blessing. If the rhythm is broken or stopped it is feared that the whole clan of the boys at the morung will be wiped out. After the blessing they move to the courtyard and perform the whoop (Mavo sou di). Meanwhile two young boys go to the ritual pond to fetch water. When the water is brought the eldest makes a cup out of plantain leave. He then fills the plantain cup with the water from ritual pond and pours the water over the head of the two small boys at the entrance of the house called paphi (place for milling paddy). The boys should not be shocked as the cold water is poured over their head. This is a sign of good omen.

These same boys go to the jungle to bring a shrub called amousü (scientific name Rhus glabra) and places it at three corners of the

${ }^{24}$ Haba, "Laonii Festival in Zhaimai Village," July 15, 2016. 


\section{2 / Paul Punii \& Dominic Meyieho}

Salesian Journal of Humanities and Social Sciences, Vol. XI, No.2 (Dec 2020)

ISSN: 0976-1861 | DOI: 10.51818/SJHSS.11.2020.77-105 | Page: 77-105,

Section: Articles

house; this is called Shu pokhai di (keeping the shu). These pieces of wood will be used for the starting of new fire (mei la di) the following year during the day of male purification ceremony -Chazü.

Secondly, on this day house warming ceremony is conducted for those who had built new houses between the months of Donü (December) and Süpa (February). Two young boys accompany the host for the house warming ceremony where they perform Chidzü. It is a day of genna. The two boys fetch water from the ritual pond and fetch water for the ritual. They then go to the forest and bring branches of Amousü and pierce it to the three corners of the house. The host first offers libation to the house deity, (tipping some wine in the inner side of his self) then offers wine in the plantain leave to the two boys assisting him in the ritual. They observe this ritual till noon when they are allowed to have their food. It is called Lee di (it is period of fasting and observance). After food they are allowed to go home. In the evening the mother performs the Hrailu thro thro.

\section{Paonü ho nuh/ Ritual work day}

On this day people go to the field for work but come back early. It is a time for cleaning the surroundings of the field. They weed out the long grass and plants on the side of the field and clear the path. This activity is done as part of the ritual during the feast.

\section{Mou ra sou/ Prayer for good seeds}

On this day the people do not go to the field but stay home and pray for good fruit and crops. They pray that the paddy be protected against hailstorms and pestilence. The people observe the day as holy without doing the ordinary works of weeding, working etc...

\section{Chazü/ Male purification ceremony}

Chaz $\ddot{u}$ is the purification ceremony for the male child. This purification ritual is done after a child completes one year or more. This ritual can be done any time after one year to five years of age, 
The Poumai Naga Agricultural Festivals and Rituals vis-a-vis Folklores... / 93

Salesian Journal of Humanities and Social Sciences, Vol. XI, No.2 (Dec 2020)

ISSN: 0976-1861 | DOI: 10.51818/SJHSS.11.2020.77-105 | Page: 77-105,

Section: Articles

when the child has become sturdy. The ritual is performed with the belief that he is strong enough to mature into a fully human being. The parents can now claim the child physically and spiritually.

A young boy assists and performs the rites for the child. In the morning the first duty of the assistant is to churn out new fire from the Amousü which was kept the previous year during Chidzü ceremony. The process is called mei la di - making of new fire. Once the fire is ignited the assistant plants three stones in a tripod shape, plus the fourth small one behind another big stone called thaopa. The thaopa signifies prayer for unity and fellowship among brothers.

The young boy then goes to the ritual pond to fetch water. He carries the pitcher Pouli in the basket shoro. He holds the spear on the right hand and in the left hand he holds a gourd mug, a sickle and rumex leave malou. The spear is a symbol of the male warrior, and malou a medicine to ward off evil spirits. The sickle and the gourd is a symbol of domestic work. This water brought is used for all ritualistic and cooking purposes of the Chazü ceremony.

Once the young boy gets home he takes the dried Mahurai (a creeper) and prepares a necklace-like cord with the malou stem. The child is then made to sit on the small seat called shobuh. The three cords are then tied, one on the left leg, one on the right hand and one around the neck. This symbol is a prefiguration of the child, when as a man he would go out for war and challenge his enemies and shout hi oh (a cry of challenge). When he shouts hi oh his left leg steps forward holding a knife or spear in the right hand. And in the fight whoever wins beheads the other as a war trophy. And so Chazü is a symbolic ritual of purification and victory of the child.

With the water brought earlier from the ritual pond the young man dabs it to different joints of the body. He first dabs the water on the crown of the head, then ears, shoulders, elbow, wrists, heart, hip joints, knees, and ankles. This is a blessing for the strength and good health of the child. All these rituals are performed at the paphi (place where rice is milled). 


\section{4 / Paul Punii \& Dominic Meyieho}

Salesian Journal of Humanities and Social Sciences, Vol. XI, No.2 (Dec 2020)

ISSN: 0976-1861 | DOI: 10.51818/SJHSS.11.2020.77-105 | Page: 77-105,

Section: Articles

The young man then holds the hand of the child and kills a cock in his name by piercing it with a sharp bamboo at the side. After the cock is killed he plucks out the heart which will be cooked and offered to the deity of the house during hrailu thro thro which will be performed in the evening. The young man then ceremoniously prepares rice (kay thou) and chicken to feed the child. The rice and curry are cooked in pouli, specially reserved only for this ritual. The spoons and ladles used for this ritual are kept separately. The leftover of the rice that is cooked for the ritual to feed the boy is then rolled tight in the plantain leave and kept in one corner of the roof. It is believed that the tightly rolled rice will bring good health to the child. The Chazü ritual for the boy will officially be over after performing chidzü and hrailu thro thro. At the time of hrailu thro thro the mother cuts a piece of ginger and slowly throws it to the ground. Both the pieces should land flat with the plan side on the floor. This is good omen.

The young man than continues to cook food for himself and other male members of the family. All these rituals are performed at the guidance and instruction of the father. The father performs the Chidzü ritual and continues to fast till noon. The mother and the girls of the family kill a young hen for themselves in the inner chamber of the house. They do not share in the rituals and food of the father and male members.

On this day another ritual called Leutoudi is performed by a Meshemai. Meshemais are those people who have performed the feast of Merit (offered wine and meat to the whole village). They observe the ritual of prayer and fasting near paphi where the altar of buffalo head has been hung. They have a little food in the afternoon. Sometimes this ritual of prayer and fast goes even up to five days. He observes these days as sacred to thank god for the wealth and prosperity given to him. He also pray to god to bless the Laonü festival.

On this day the animals are killed for the celebration of the Laonü festival. The rich and poor alike kill lots of chicken, pigs, 
The Poumai Naga Agricultural Festivals and Rituals vis-a-vis Folklores... / 95

Salesian Journal of Humanities and Social Sciences, Vol. XI, No.2 (Dec 2020)

ISSN: 0976-1861 | DOI: 10.51818/SJHSS.11.2020.77-105 | Page: 77-105,

Section: Articles

dogs, cows and buffaloes reared for this occasion. Every family in the village prepare lots of rice beer zou for the feast. The Laonü festival is celebrated with great pomp and enjoyment. Lots of meat is bought by the families also to give as sou majhü (a portion of meat) to daughters and sisters who are married. It is also on this day that sisters and guests from other villages come to the village to celebrate the festival.

\section{Chidzï/ Prayer to the home deity}

The ritual of chidzü is performed on this day. It is a day of genna. In this ritual chidzü is the source and origin of all other chidzü. And in the evening hralu thro thro is performed. The daughters or sisters who are married and who come from other villages and guests are invited to their father's / brother's home and fed with good food and drinks. This day is also called nüdu (big feast) the most important day in the Laonü festival. Everyone in the village enjoys with good food and drinks. On this day young boys gather in their peers to spend time together exchanging food and drinks. So also girls in their groups enjoy and share food and drinks according to their morung. It is a genna to go to the field.

\section{Shepao/ Bidding farewell to the guest}

On this day the daughters, sisters and guests who came from other villages return to their home. They are sent off with lots of meat, local bread, food, drinks and vegetables.

In Zhaimai village, in the evening of these three important days of Chazü, Chidzü, and Shepao the young men and children of the village play Vai-o. This dance is known and performed only in Zhaimai village. It begins with Mavo whoopi done khel wise, then the young men gather together to perform the Vai-o. It's a dance exhibiting joy, celebration, khel unity and village unity. 


\section{6 / Paul Punii \& Dominic Meyieho}

Salesian Journal of Humanities and Social Sciences, Vol. XI, No.2 (Dec 2020)

ISSN: 0976-1861 | DOI: 10.51818/SJHSS.11.2020.77-105 | Page: 77-105,

Section: Articles

\section{Khaphya/ Fishing day}

The word Khaphya literally means fishes are let out. It is a day when the womenfolk go to the field and river to fish. They would try to catch as much fish as possible because on the way young boys would wait to see who caught more, and ask for contribution. The boys in their turn would cook good meat and bring to have party with them in their morung.

\section{Putou Chupo/ Wrestling day}

On this day young boys would gather in a large village courtyard to have wrestling. The winner would be proclaimed as the strongest man in the village. To be acclaimed such was a pride and honour for him and the family. Wrestling is a very ancient game of the Nagas where courage and manliness is shone. Sometimes fights and quarrels in the villages were settled through wrestling. Those who were strong and knew how to wrestle were considered heroes in the village.

\section{Sou ba nai/ Last feast}

The feast slowly comes to an end in the village. Those who killed animals in the village for the feast will conclude the feast with the limbs of the animals. Sou ba nai would mean feasting on the left overs / limbs of the meat.

\section{Nï tew/ End of the feast}

$N \ddot{u}$ teu means end of the feast. This day officially ends the feast of Laonü. After this day the chief of the village will officially declare open the collection of Lou. Lou is a nettle plant whose crust is peeled and processed to make clothes. After this day people begin to assume their normal work and activity. 
The Poumai Naga Agricultural Festivals and Rituals vis-a-vis Folklores... / 97

Salesian Journal of Humanities and Social Sciences, Vol. XI, No.2 (Dec 2020)

ISSN: 0976-1861 | DOI: 10.51818/SJHSS.11.2020.77-105 | Page: 77-105,

Section: Articles

\section{Nge/ Prayer for Preservation from Pestilence}

Nge is the name of the month of September in Poula. However it also refers to the ritual that is observed for three days. People pray and worship the sky and earth so that the fruits of their fields may be protected from thunder-storm and bad weather. All members of the village observe these days with great sacredness. It is a day of genna. No one should go to the field or forest-no one should even dry their clothes in sun. Even children and youth are not allowed to play any type of games. There should not be any form of fun fare and revelry even prohibiting marital and conjugal relationships. This year due to the pandemic COVID-19, the ritual was observed with even greater sacredness.

\section{Nge dzii/ Ritual day of prayer to deity}

This is the first day of Nge observation where Chidzü ritual is performed. In the afternoon an unblemished heifer is drawn into the village Chief's courtyard for a symbolic ritual. The heifer is tied to a post in the Chief's courtyard for a day and released in the evening. This process is carried out for three consecutive days to be a forecast for the climatic conditions of the year.

\section{Nge pa/ Second day of Nge}

This is the second day when the Chief ties the heifer in the courtyard and he observes the direction of the mooing of the heifer. It is believed that if the heifer moos facing the east, then hailstorms are expected in the east, and if it moos facing the west, hailstorms are expected in the west. According to Saranamai tradition, on this day a dog (called Thepao) is sacrificed by the Chief. Pieces of this meat are distributed to every household to perform the sin offering oblation. All meat pieces should be consumed on the same day. 


\section{8 / Paul Punii \& Dominic Meyieho}

Salesian Journal of Humanities and Social Sciences, Vol. XI, No.2 (Dec 2020)

ISSN: 0976-1861 | DOI: 10.51818/SJHSS.11.2020.77-105 | Page: 77-105,

Section: Articles

\section{Nge veih hro/ Release of the heifer}

This is the day when the heifer is released from being tied in the courtyard of the king and so the name veih hro (heifer released from being tied). The leaf of the ficus tree bousü is placed in front of the house as a symbolic ritual of cleansing and protection for the house. Members of the family are forbidden to consume meat on this day. ${ }^{25}$

\section{Saka/Ritual cursing of the Cat}

Every year in the month of Yupfo khou October, a day is set aside to perform saka. Saka literally means sa cat, $k a$ curse. This curse is performed against those who might not have observed properly the Duh and Nge ritual thus leading to drought, bad weather, thunderstorm and poor harvest. A cat is ensnared in a small bamboo basket and smashed to death with a stone, leading to loud cry and struggle. All the people gather and curse saying oh thuih (throwing out spittle as a sign of repugnance), when the leader shouts and puts forward the intention like those who refused to perform the rituals, those who steal others things, who possess evil spirits, and who tend to claim others property. In the mean while an old man kills the cat, symbolising the struggle these people should have at their death.

\section{Thotho/ Thanksgiving for the New Harvest}

This is a ritual of offering the first fruits to God. There are two times this ritual is performed. The first ritual is done at the time of Khana khou (May) when millet, cucumber and other fruits are harvested. And the second ritual is performed before Nge (September). At the time of plantation some paddy plants are planted near the house. This is used for the first offering to the deity. The village chief announces and performs the ritual on the first day and the villages follow suit the next day. In the present times the offering is symbolic and can be done in the morning or evening. The new fruit grains,

${ }^{25}$ Materou Dorothy, The Siimai Tyahrii Nii: Kindred Fest 2010 (Senapati: Siimai Tyahrii Nii Committee, 2010), 47. 
The Poumai Naga Agricultural Festivals and Rituals vis-a-vis Folklores... / 99

Salesian Journal of Humanities and Social Sciences, Vol. XI, No.2 (Dec 2020)

ISSN: 0976-1861 | DOI: 10.51818/SJHSS.11.2020.77-105 | Page: 77-105,

Section: Articles

rice is placed into the pot and cooked. When it is cooked, two tiny plantain leaves are placed on the right and left of the plate, a little rice is placed on the leaves for grandma tro and grandpa hralu. Then the children are fed saying, "Thothou hai toulou-a, ramaha buh-o," (We are eating first fruits, eat and be blessed). Before this offering is done it is a forbidden $n y u$ to eat any new produce of the field. ${ }^{26}$

\section{Baoloutouyu/Inauguration of the New Rice Barn}

This is a very sacred ritual which is performed in the family before using any grains from the barn. The word baoloutou is made up of three words, bao means rice barn, lou means to take from and tou means eat. So baoloutou would mean to take from the barn and eat. This ritual begins on the fifth day of the new month of Donü (December). There are six ceremonious days: Bao khai sou, Bao troo lou, Baodu hradi, Lu daodi, Loudi, Baolou Veinai. ${ }^{27}$

\section{Bao khai sou/ Inauguration of the barn}

In the morning the mother goes in search of the mud silt made by the earth worm, brings home, opens the barn and spreads over the paddy, praying that the paddy must increase and multiply like the silt mud made by earthworms. She then fetches the thrübü/ shrub with strong roots and places two plants under the barn wishing for good paddy and strong roots like the plant.

\section{Bao tro low/ Refilling the barn}

This is the second day, observed especially by those who had performed the feast of Merits known as the Meshimai. Bao tro lou di literally means to fill again. The man go to their field where they had left few stalks uncut during the harvest. They bring the paddy

\footnotetext{
${ }^{26}$ Hriinii T. Henry, Khochi Paotsi and Weikho P. Sebastian, "Thounii Festival of the Poumai Nagas," interview by Paul Punii, October 16, 2016.

${ }^{27}$ Punii Michael, "Poumai Baolutoudi," interviewed by Paul Punii, October 22, 2016.
} 


\section{0 / Paul Punii \& Dominic Meyieho}

Salesian Journal of Humanities and Social Sciences, Vol. XI, No.2 (Dec 2020)

ISSN: 0976-1861 | DOI: 10.51818/SJHSS.11.2020.77-105 | Page: 77-105,

Section: Articles

home and spread over the other paddy. It is a prayer and a sign for abundance.

\section{Baodu hra/ Opening of the big barn}

The word baodu hra literally means to open the big barn. On this third day a young innocent girl is chosen from the family or the neighbourhood to bless the barn. She should cover her head with a veil. She should not have eaten any jungle meat, meat offered to idols and Pyaasou - meat served in honour of the dead. The mother or father fetches water from the ritual pond and soaks millet grains in it. The young girl then picks a few millet grains and throws into the rice barn. This same young girl can perform the ritual for other families too. They all feed her after the ceremony. The part of this girl can also be performed by a Meshimai woman. After meal men go to the river and fields to catch crabs and khanü (tiny freshwater fish). Crabs are brought home and given to the girl who performs the blessing of the barn and for their own consumption. The fish khanü is brought home and in the evening the mother rubs the four corners of the barn, and also uses for consumption. After performing this ritual she eats her food and goes to rest. This should be the last activity of the day.

According to Heshoru Dio, in the Lepaona tradition, the young girl is called the Lüpüti fairy. Two lüpüti fairies are chosen by the elders from the village who will stay in the village Chief's house till the Baoloutouyu ceremony is over. When the womenfolk brings khanü small fish from the field, these two little fairies will be carried around and go to every house to smear khanü at the corner of the rice barn. This ritual is done to seek the blessings of the fairies so that food grains may last till the end of the year. ${ }^{28}$

\section{Lu dao di/ Ritual digging of the field}

On the fourth day the man offers libation to the home deity and goes to dig the field as part of a ritual. The woman cooks food and

${ }^{28}$ Dio, Paih-Pao Maivei Zhaidou, 27. 
The Poumai Naga Agricultural Festivals and Rituals vis-a-vis Folklores... / 101

Salesian Journal of Humanities and Social Sciences, Vol. XI, No.2 (Dec 2020)

ISSN: 0976-1861 | DOI: 10.51818/SJHSS.11.2020.77-105 | Page: 77-105,

Section: Articles

gives a feast to the grandchildren. All the grandchildren are fed as a sign of abundance. With this the bao loutouyu ceremony comes to an end.

\section{Lou di/Collecting thatch}

On this day the man who would like to make new houses get up early (for fear others will collect before him), kills a chicken and go to collect thatch grass for making houses. However he brings thatch grass and keeps the bundle outside the village gate. He comes the next day to carry home the bundle of thatch grass. Young boys and girls go to the forest to collect bü (a long stalky plant called himalayan lily) and zaolu (a tree that produces large bean sized seeds) for children to play. The season is thus open for the children and young people to play and have fun with these instruments. ${ }^{29}$

\section{Thonü / New Year Festival}

Thonü is one most popular agricultural and customary festival of the Poumai Nagas celebrated every year after the harvest. According to the Poumai Naga Lunar calendar it falls at the new moon after the winter solstice somewhere between the months of December and January. The word Thounü literally means feast of new paddy. The month when this feast is celebrated is called Thounü khou. Presently people celebrate it as Poumai New year. It was decided in the year 2012 by the Poumai Naga Union (PNU), that Poumai Thounü will be celebrated and commemorated on $5^{\text {th }}$ of January every year. It is a month where people give thanks to God for tho thou (fresh paddy). The Thounü festival is an occasion to thank God for the good harvest. It is considered as one of the biggest and grandest festival because of the attribution of pleasant climate, abundance of food grains, drinks and the festive mood of the people. Even as the

feast is approaching, hopefully the people will refrain from large public gatherings due to COVID-19.

${ }^{29}$ Michael, “Poumai Baolutoudi," October 22, 2016. 


\section{2 / Paul Punii \& Dominic Meyieho}

Salesian Journal of Humanities and Social Sciences, Vol. XI, No.2 (Dec 2020)

ISSN: 0976-1861 | DOI: 10.51818/SJHSS.11.2020.77-105 | Page: 77-105,

Section: Articles

The celebration of the Thounü is announced by the village chief seven days ahead before the actual feast day. The people then begin to prepare for the celebration especially drying and milling the paddy for brewing rice beer. The Thounü is celebrated for five days Thounü sha, Thounü nüdu, Shepao, Thounü dai, Thounü ngou. ${ }^{30}$

\section{Thounü Sha/ First day of Celebration}

The first day of the festival is known as Shaa/Saa. This day is marked as the day of rejoicing and happiness. It's a preparation day for the festival. Animals like dog, pig, cow and buffaloes for the feast are killed. The rice beer prepared for the feast is blessed and tasted on this day. In the evening the family members sit together and bake bread on a hot flat stone. The bread is made of powdered rice, and sesame paste is applied on the bread for better taste. Daughters and guest from other villages arrive on this day.

People clean the surroundings of their house and the streets, roads and stone courtyards. Young people go in groups to clean the village approach roads. These youngsters collect wine from the villagers as price for cleaning the approach roads and gather in the evening to celebrate at the morung.

\section{Thounü Chidzï/Second day}

The second day of the festival is the main day of the feast spent in eating and drinking and merry making. The father of the family performs the chidzü says a prayer and offers meat and ginger and libation of wine to the house deity at the rüphi. Friends and families gather in groups sharing food, drinks, singing folks songs and telling stories. Young boys and girls, even children gather in groups to celebrate the feast. In the evening, when all have eaten and before going to sleep the mother performs the final ritual of hrailu thro thro, offering of food to the home deity.

${ }^{30}$ Silas H. Zho, "The Poumai Naga Thounii: The Most Popular Coustomary Festival," in Poumai Thounii Celebration: Our Culture is our Identity Paul Punii(ed.), (Senapati: Poumai Thounii Committee, 2016), 4-6;41-42. 
The Poumai Naga Agricultural Festivals and Rituals vis-a-vis Folklores... / 103

Salesian Journal of Humanities and Social Sciences, Vol. XI, No.2 (Dec 2020)

ISSN: 0976-1861 | DOI: 10.51818/SJHSS.11.2020.77-105 | Page: 77-105,

Section: Articles

\section{Thounü shepao/ Bidding farewell}

Thounü shepao is the day when the relatives and guests are escorted back after the festival. They are sent back with lots of food pack, raw meat and drinks for themselves and for their relatives. The more the gifts carried, the wealthier they are thought to be by the relatives.

\section{Thounï dai/ Fourth day}

The fourth day of Thounü is celebrated with dance and sporting activities among the people. Indigenous sports like shot-put with stones of various sizes, weight lifting, and javelin throw with long wooden pestle; long jump and high jump are played on this day. The traditional war dance is an essential part of the festival and is performed in groups especially by the youngsters. They are performed by players clad in full traditional attires.

\section{Thounü ngow/Fifth day}

It is the fifth day of the feast day. The celebration with food, drinks and traditional games and dances continue even to this day. It is an extension of the previous day's celebration.

\section{Other Significance}

The Thounü season also marks the initiation of new village settlements after considering the various aspects and observation of omens, dreams, signs and divination etc...Thounü is also the time when joh shudi takes place. Joh shudi literally means sharing food pack which she brought from her parent's home. It is a feast where the newly married bride prepares good rice beer with paddy brought from her parents and offers to the grooms parents, uncles, brothers and cousins. This officially makes the bride welcomed into the family and the clan. Henceforth she becomes their daughter and

their sister. Later these uncles and brothers will invite the couple for a meal. 
Salesian Journal of Humanities and Social Sciences, Vol. XI, No.2 (Dec 2020)

ISSN: 0976-1861 | DOI: 10.51818/SJHSS.11.2020.77-105 | Page: 77-105,

Section: Articles

\section{Response to Covid-19 Pandemic}

The Covid-19 pandemic and the extent of its worldwide fatal experience is first of its kind that most people around the world are experiencing in their life time. The pandemic is portrayed as such a fearful thing also because of the round the clock bombardment of Covid-19 news by media. A similar sickness of this nature, but of lesser degree is the small pox of 1974, of which many elders in the villages have some memory. There are other natural disasters like, droughts, landslides and hailstorms that destroy paddy and rice grains. It is in these situations that the people were religiously reminded to observe the rituals of Duh and Nge devoutly.

The ritual days of Duh in the month of May, just before the plantation and the ritual days of $\mathrm{Nge}$ in the month of September before the harvest begins are very sacred days and calls for the sanctimonious observance of these days. As narrated above, on these days all the members of the village participate in offering prayer and wine libation to the deity, observe fast, and refrain from revelry. The strict and sanctimonious observance of these days is very important and it is believed that indiscipline and defying of the sanctimony of these days will bring ill fate to them. The law breakers especially will be affected by diseases, epidemic and pandemics.

As for the Poumai people and its villages, since the people are basically agrarian even when the lockdown was imposed by the Government of India on $25^{\text {th }}$ March 2020, they continued their normal agricultural activity of plantation, weeding and harvest. The schooling of children, travel outside the village to cities, and business communities were affected but agricultural lives of the people in general were unaffected by the Covid-19. 
The Poumai Naga Agricultural Festivals and Rituals vis-a-vis Folklores... / 105

Salesian Journal of Humanities and Social Sciences, Vol. XI, No.2 (Dec 2020)

ISSN: 0976-1861 | DOI: 10.51818/SJHSS.11.2020.77-105 | Page: 77-105,

Section: Articles

\section{Conclusion}

In the description of the above Poumai Naga festivals and their concurrent rituals we see a strong underlying socio-religious structure that stands out to form an identity and a tradition. These socio-religious practice of the folks etches the historico-cultural heritage on the fabric of the Poumai identity. In all festivals three days clearly stand out-Sha the preparation day, chidzü; worship and celebration and shepao; celebration and farewell for the relatives. The festivals are held after the new moon of every month. Sacrificing of birds and animals and other activities are part of these celebrations. The observance and celebration of these agricultural festivals performs certain functions in the society. In many cases rituals teach us the rules, beliefs and attitudes necessary for our functioning in the society in which we live.

These agricultural festivals, rituals and practices were considered sacred and are practiced across the villages where the people are commonly bound by Poula language. These conceptual linguistic frameworks of festivals, rituals and practices can be called what leads to the establishment of the Poumai Naga identity and tradition. The annual celebration and performance of these feasts and rituals persuades the people to believe that the values portrayed or referred to during the rituals are true values. In the words of Martha C. Sims and Martine Stephens, the community is built, "by enacting rituals that expresses their beliefs and values, [and] they hope to influence group members to live according to the principles that rituals embody, thereby creating a ...community that possess and promotes those values." ${ }^{31}$ In the presentation and analyses of these Poumai Naga Agricultural festivals one can find that the people are religious with lots of rituals to be performed, socially oriented with many community celebrations and sibling bonding, culturally beautiful with variety of costumes, artefacts, signs and symbols to give meaning to the folkloric tradition.

${ }^{31}$ Sims and Stephens, Living Folklore, 101. 